\title{
Application of High Temperature Nuclear Reactor for Petrochemical Industry
}

\author{
D. H. Salimy, A. Hafid \\ Center for Nuclear Reactor Technology and Safety (PTKRN) \\ National Nuclear Energy Agency of Indonesia (BATAN) \\ Puspiptek Area Serpong Tangerang Selatan 15310 Indonesia
}

\begin{abstract}
Paper reviewing high temperature nuclear reactor applications as a source of heat energy in the petrochemical industry. Application for a urea fertilizer plant with a capacity of 1725 tons per day, showing the use of high-temperature nuclear reactors can save natural gas by about $\mathbf{1 2 . 3}$ million MMBTU/year which is equivalent to a reduction in $\mathrm{CO}_{2}$ emissions of 718,192.42 million tons/year. The nuclear reactor with the thermal capacity of $600 \mathrm{MWt}$, is enough to supply heat energy in the form of process heat, process steam, and electricity. The excess energy of about $101.44 \mathrm{MWt}$ is converted to electricity of 54.2 MWe, send to the public grid. While applications at oil refineries, high-temperature nuclear reactors with a power of $250 \mathrm{MWt}$ can meet the needs of steam and electricity for oil refineries with a capacity of $126 \mathrm{MBSD}$, with excess electricity of $8.93 \mathrm{MWe}$. The replacement of conventional heat sources with nuclear power can save as much as 64.8 thousand tons/year of fossil fuels which is equivalent to the potential reduction in $\mathrm{CO}_{2}$ emissions by 182.4 thousand tons / year. Several other applications of high nuclear reactors for industry are also discussed.
\end{abstract}

Keywords-Urea fertilizer; steam reforming; process heat; process steam; refinery; nuclear reactor

\section{INTRODUCTION}

In general, the policy of utilizing nuclear energy for electricity generation and cogeneration in Indonesia is the realization of the role of nuclear energy in a symbiotic and synergistic manner with non-renewable and renewable energy resources to meet national energy needs to support sustainable development. For this reason, in addition to encouraging the establishment of the first nuclear power plant in Indonesia, BATAN also must continue to conduct various studies of future nuclear reactors such as: the concept of cogeneration reactors for the production of clean water (desalination), the use of process heat for high temperature and medium industrial operations such as hydrogen production, gasification coal, oil refineries, and others

This paper is a review of $\mathrm{R} \& \mathrm{D}$ activities for high temperature nuclear reactor applications for the petrochemical industry, one of the industries that require large amounts of energy to operate it. Nuclear energy is expected to be thermal energy source of process in the petrochemical industry. The petrochemical processes that have been studied previously include: HTGR for the production of urea fertilizer, oil refineries, and $\mathrm{CO}_{2}$ conversion. The important petrochemical processes reviewed in this paper are urea fertilizers and oil refineries, two of petrochemical industries that require large amounts of energy.

Urea fertilizer is an artificial component containing elements of carbon, hydrogen, oxygen and nitrogen. This fertilizer is produced with natural gas (or other light hydrocarbons) and air as a nitrogen source. Conventionally, urea fertilizer production is carried out through the process of natural gas steam reforming to form hydrogen $\left(\mathrm{H}_{2}\right)$ and carbon monoxide $(\mathrm{CO})$, then reacted with nitrogen $\left(\mathrm{N}_{2}\right)$ from the air to form ammonia $\left(\mathrm{NH}_{3}\right)$, and finally with $\mathrm{CO}_{2}$ formed urea. The process of natural gas steam reforming is the main key of the process. This process is an endothermic process that operates at high temperatures $\left(\sim 800^{\circ} \mathrm{C}\right)$ so that it requires large amounts of thermal energy, that convensionally supplied by fossil fuel. $f$ the use of fossil fuel of natural gas as a source of energy can be replaced with nuclear, there will be significant benefits in terms of saving natural gas, and a significant reduction in $\mathrm{CO}_{2}$ emissions.

Oil refinery is factories / industrial facilities that process crude oil into petroleum products that can be directly used or other products that become raw materials for the petrochemical industry [1]. The operating temperature at the oil refinery varies from low temperature (room) to high temperature $\left(800^{\circ} \mathrm{C}\right)$. In general, the energy needed at oil refineries includes: process heat, process steam, and electricity. Process heat is needed to run processes that operate at high temperatures $\left(400-800^{\circ} \mathrm{C}\right)$, while the process steam and electricity are used to run processes that operate at low temperatures. Conventionally, oil refineries use part of their oil products as a source of energy for processing inside refineries. A study indicates that to operate an oil refinery, around $10-20 \%$ of refinery products must be burned as a source of energy (including steam and electricity). If nuclear energy can be used as a source of energy, it is expected to benefit from reduction of burning fossil fuels, which has implications for the potential for $\mathrm{CO}_{2}$ emission savings.

The concept of nuclear energy as a source of thermal energy for industry has been studied for more than 50 years. Gas-cooled high temperature reactor (HTGR, High Temperature Gas cooled Reactor) which operates at high temperatures $\left(\sim 1000^{\circ} \mathrm{C}\right)$ and fast breeding reactors (FBR, Fast Breeder Reactor) which operate at temperatures of $500-700^{\circ} \mathrm{C}$ are thought to be a type of reactor that has the potential to contribute to production thermal energy for industrial needs. One application of high temperature nuclear reactor technology is the process of natural gas steam reforming to produce hydrogen. Several countries such as Japan, Germany, 
China and South Africa conducted a very intensive study of the process of natural gas steam reforming with high temperature nuclear reactors $[2,3]$. The country with the most advanced R \& D today is Japan. Since the 1990s, Japan has been operating HTGR reactors called HTTR (High Temperature Engineering Testing Reactor) to be coupled with the production of hydrogen and methanol. Since the 2000s Japan has built a nuclear coupled demonstration plant with the natural gas steam reforming process to produce hydrogen and methanol [4].

\section{NUCLEAR AS THERMAL ENERGY SOURCE}

\subsection{Nuclear cogeneration}

Cogeneration, also known as combined heat and power (CHP), is a very efficient; clean; and reliable approach to generate power and thermal energy from a single fuel source [5]. Typically, cogeneration plants recover percentage of the waste heat that is otherwise discarded from conventional power generation. The recovered waste heat is effectively utilized in other thermal energy applications. Current nuclear power plants have low thermal efficiencies generally in the range of 30 to $35 \%$ compared to other steam cycle energy conversion systems. Countries embarking on nuclear power should consider co-generation and the use of waste heat from a NPP to increase energy utilization and overall efficiency.

In a number of countries, co-generation and heat production using nuclear reactors is already an effective way to meet different types of energy needs. Currently, there are 79 reactors operating in cogeneration mode and the potential for applying this technology more widely appears promising [6,7]. Heat applications cover a wide range of specific temperature requirements starting from low temperatures i.e., just above room temperature for applications such as hot water and steam for agro-industry, district heating, and sea water desalination; reaching more than $1000^{\circ} \mathrm{C}$ for process steam and heat applications i.e., for chemical industry and high-pressure injection steam, enhanced oil recovery, oil shale and oil sand processing, oil refinery, refinement of coal and lignite, and water splitting for the production of hydrogen. With the rapid increase in energy demand (for both electricity and heat), concern over global warming could pave the way for nuclear energy to exert a major positive impact on energy security and climate change.

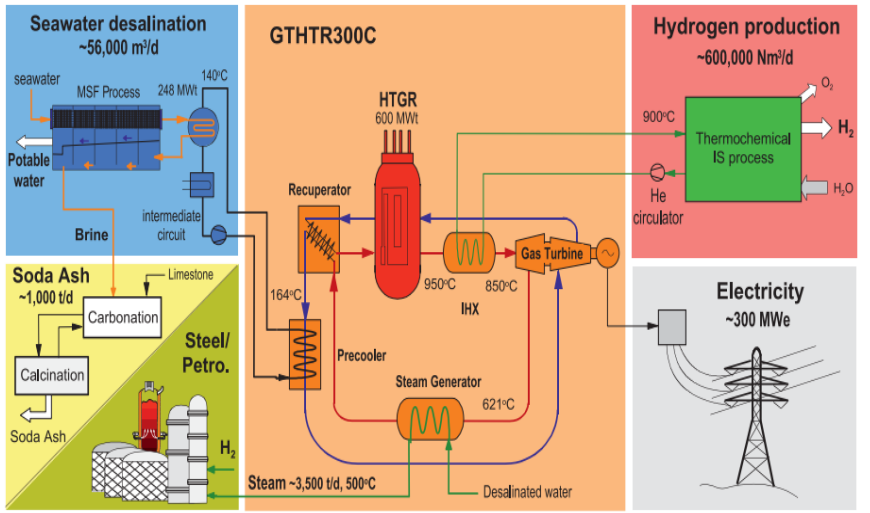

Fig. 1. HTGR Application for electricity, hydrogen, and desalination [8]
Figure 1 shows the ability of high temperature nuclear reactors to provide heat for hydrogen production, petrochemical processes and iron industries, as well as clean water. Thermal energy produced from nuclear and hydrogen can be a basic component to operate various processes in the petrochemical industry.

\subsection{Nuclear heat for refinery}

The study of high temperature nuclear reactor applications for oil refinery and petrochemical industries has been carried out in several countries, one of them in China [9]. In the late 1980s, China collaborated with Germany to study the use of high temperature nuclear reactors for the petrochemical industry (including oil refineries) in the Yan Shan Petrochemical General Corporation (YSPGC) industrial area. Energy consumption in this industrial complex is conventionally supplied by burning 1.2 million tons of oil per year. Total steam needs at different pressures and temperatures, varying from 730 tons/hour in summer to 1650 tons/hour in winter. The steam parameters are: 118 bar $/ 500^{\circ} \mathrm{C}, 47-50 \mathrm{bar} / 450^{\circ} \mathrm{C}, 34-39 \mathrm{bar} / 350^{\circ} \mathrm{C}$, and $8-13$ bar $/ 280^{\circ} \mathrm{C}$, with the main energy supplier coming from the steam - electric fuel oil cogeneration system. The results of the study indicate that the need of steam for the above process can be met by operating 4 units of high temperature nuclear reactors each with a capacity of $200 \mathrm{MWt}$. Operation by cogeneration to four nuclear reactor units can supply: 139 MWe electricity, 30 tons/hour of steam $\left(118 \mathrm{bar} / 500^{\circ} \mathrm{C}\right), 73$ tons/hour of steam $\left(48 \mathrm{bar} / 450^{\circ} \mathrm{C}\right), 310$ tons/hour of steam $\left(36 \mathrm{bar} / 350^{\circ} \mathrm{C}\right)$, and 500 tons $/$ hour of steam $\left(10 \mathrm{bar} / 280^{\circ} \mathrm{C}\right)$.

In Indonesia a study of nuclear energy applications for oil refineries has also been carried out $[10,11]$. One of the oil refineries in Indonesia is used as a reference refinery. A refinery with a capacity of $126 \mathrm{MBSD}$ of crude oil and capable of producing various transportation fuels and other products, will operate by nuclear as a heat source. To operate a refinery, steam requirement are as follow: process steam 1 $\left(385^{\circ} \mathrm{C}, 40 \mathrm{~kg} / \mathrm{cm}^{2}\right)$ with a rate of 55.6 tons/hour, and process steam $2\left(360^{\circ} \mathrm{C}, 15 \mathrm{~kg} / \mathrm{cm}^{2}\right)$ with the rate of $131.1 \mathrm{ton} /$ hour. To generate the steam, oil is needed as fuel. In addition, to support the operations of refinery, offices and housing, electricity is needed as much 24 MWe generated by gas turbine.

If nuclear energy is used as a source of energy, nuclear must be able to meet the energy needs for the process steam and electricity on demand that have been supplied with fuel. The study chose HTR-PM250, which is a Chinese high temperature type reactor with a thermal capacity of $250 \mathrm{MWt}$ [12]. The calculation results can be seen in the Table 1 .

Table 1. Balance of nuclear energy for refinery

\begin{tabular}{ll}
\hline Energy Supply & \\
Power output of HTR PM250 & $250 \mathrm{MWt}$ \\
Thermal efficiency of IHX & $90 \%$ \\
Output of IHX & $225 \mathrm{MWt}$ \\
\hline Energy Demand & \\
Steam $1\left(385^{\circ} \mathrm{C}, 40 \mathrm{~kg} / \mathrm{cm}^{2}, 55.6 \mathrm{ton} /\right.$ hour $)$ & $41.23 \mathrm{MWt}$ \\
Steam $2\left(360^{\circ} \mathrm{C}, 15 \mathrm{~kg} / \mathrm{cm}^{2}, 131.1 \mathrm{ton} /\right.$ hour $)$ & $101.47 \mathrm{MWt}$ \\
Electricity $(24 \mathrm{MWe})$ & $60 \mathrm{MWt}$ \\
Total Demand & $202.7 \mathrm{MWt}$ \\
\hline Exess energy & $22.3 \mathrm{MWt} \sim 8.93 \mathrm{MWe}$ \\
\hline
\end{tabular}


From Table 1, it can be seen that nuclear reactors with a thermal power of $250 \mathrm{MWt}$ can be used to meet the needs of steam and electricity at oil refineries with a crude oil processing capacity of $126 \mathrm{MBSD}$, with an excess of thermal energy of 22.3 MWth which can be converted into electricity of $8.93 \mathrm{MWe}$ to be connected to the public electricity network. The replacement of fossil fuels for steaming and electricity production at the refinery, provides savings on burning fossil fuels by 64,800 tons/year. This savings has implications for the potential for $\mathrm{CO}_{2}$ emission reduction of 182.4 thousand tons/year.

Schematic diagram of high temperature nuclear reactor for electricity and steam production for refinery is shown in Figure 2. Intermediate Heat Exhcanger is used to separate between nuclear and nuclear island. Heat energy used to application is the heat energy carried over by secondary helium.

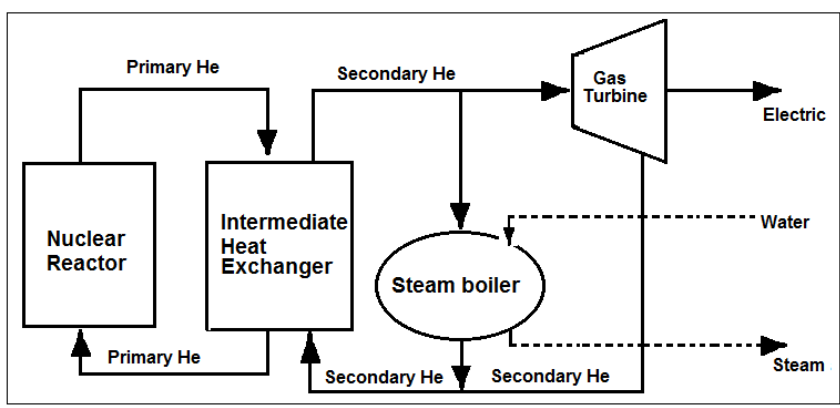

Fig. 2. Schematic diagram of nuclear for electricity and steam production for refinery

As comparisson, study of nuclear energy applications for oil refineries was carried out in France, replacing about $80 \%$ of the energy needs of oil refineries with nuclear energy [13]. Here, nuclear is used to supply electricity and the refineries a capacity of $180 \mathrm{MBSD}$ as a reference provides $\mathrm{CO} 2$ emissions savings of 350 thousand tons/year.

\subsection{Nuclear heat for urea fertilizer plant}

At the urea fertilizer plant the process of steam reforming natural gas is the main key to the process. This process is an endothermic process that operates at high temperatures ( $800^{\circ} \mathrm{C}$ ) so that it requires large amounts of thermal energy. The need for thermal energy to carry out the process is supplied from direct combustion of natural gas fossil fuels. Based on operating experience, of the total natural gas needs, only around $40 \%$ is processed as raw material. The rest is burned to supply thermal energy needs in the steam reforming process, and to meet the steam and electricity process requirements needed to run the plant.

If the nuclear can be applied to operate the process of natural gas steam reforming, it is expected that profits can be obtained in terms of saving natural gas which has implications for the reduction of $\mathrm{CO}_{2}$ emissions and diversification of nuclear reactor utilization.

The study of high temperature nuclear energy applications for fertilizer plants has been carried out in Indonesia [14,15]. In the study, data was obtained from an urea fertilizer plant that had been operating, with a capacity of 1725 tons of urea fertilizer per day. To produce urea fertilizer with this capacity, the following main raw materials are needed: natural gas 629.59 tons/day, steam 2261.88 tons/day, and air $119,733.79$ tons/day.

In the production process, the ammonia plant unit is the main unit in each urea fertilizer plant. This unit is also the unit that consumes the most heat energy. To operate a urea fertilizer plant with a capacity of 1725 tons/day, the ammonia plant unit must be able to produce hydrogen with a capacity of 198.1 tons/day. This hydrogen is produced through the steam reforming process of natural gas, with 629.59 tons of natural gas raw material per day. In conventional processes, natural gas is also used as a source of heat energy.

The total natural gas needs to produce urea fertilizer with a capacity of 1725 tons/day is $21,252,188.83$ MMBTU with details: as raw material 8,945,131.08 MMBTU, heat source energy for process $6,161,446.75 \mathrm{MMBTU}$, and as energy to produce electricity and steam 6,145,610.99 MMBTU. It is seen that the need for natural gas as raw material is only about $40 \%$ of the total needs. By utilizing high temperature nuclear reactors as a process heat source, steam and electricity, it is expected that around $60 \%$ of natural gas can be saved.

In this study, nuclear reactors used as references in calculations are Generation IV high-temperature nuclear reactors [18]. The helium gas-cooled high temperature reactor, the type GT MHR (Gas Turbine-Modular Helium Reactor) used as a reference for calculation by considering this reactor, represents the reactor is another Generation IV high temperature nuclear reactor. The heat output of the reactor coolant carried by helium gas coolers at a temperature of $\sim 1000^{\circ} \mathrm{C}$ is utilized as an energy source in the form of heat process, pocess steam and electricity. Schematic diagram of nuclear application for urea fertilizer plant is shown at Fig. 3.

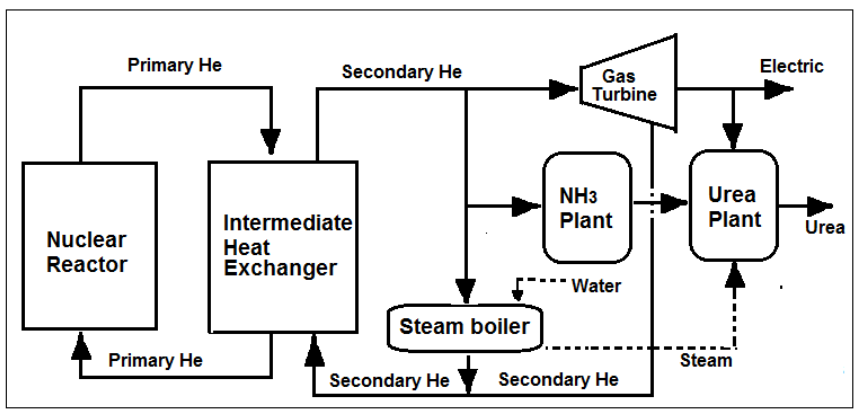

Fig. 3. Schematic diagram of nuclear application for urea fertilizer plant

Distribution of utilization of nuclear energy for fertilizer plant can be seen in the Table 2. It seen in Table 2 that $274.3 \mathrm{MWt}$ of nuclear thermal energy (abaout $46 \%$ ) is used for process heat at steam reforming process to produce hydrogen and convert them to ammonia.

Table 2. Balance of nuclear energy for urea fertilizer

\begin{tabular}{ll}
\hline Energy Supply & \\
Power output of nuclear rector & $600 \mathrm{MWt}$ \\
Thermal efficiency of IHX & $90 \%$ \\
Output of IHX & $540 \mathrm{MWt}$ \\
\hline Energy Demand & \\
Process heat for reforming process & $274.3 \mathrm{MWt}$ \\
Steam for process and electric & $101.44 \mathrm{MWt}$ \\
Total Demand & $375.34 \mathrm{MWt}$ \\
\hline Exess energy & $164.25 \mathrm{MWt} \sim 54.2 \mathrm{MWe}$ \\
\hline
\end{tabular}


The potential reduction in the rate of $\mathrm{CO}_{2}$ emissions is obtained from the savings in the use of natural gas as fuel. Utilization of high temperature nuclear reactors can meet the needs of all thermal energy needed, so that natural gas is only needed as raw material. Of the total natural gas needs per year of 21,252,188.83 MMBTU, only 8,945,131.08 MMBTU is used as raw material. The remaining about $12,307,057.75$ MMBTU per year is used as fuel. This natural gas savings of $12,307,057.75$ MMBTU per year will be equivalent to reducing $\mathrm{CO}_{2}$ emissions by $718,196.42$ tons/year.

\section{DISCUSSION}

The use of nuclear energy has mostly concentrated on producing electricity. Another established but much smaller application has been as a power source for ships: submarines, icebreakers and even merchant ships. Non-electricity applications based on direct use of heat generated in the fission process of water cooled nuclear reactors could include process heat for various low temperature industrial applications, desalination and district heating. A modern unit with a generating capacity of 1,800 MWe could also produce $1,000 \mathrm{MW}$ of heat for district heating [17]. In this case the electrical output would fall by about $200 \mathrm{MW}$, but the total efficiency would increase from less than $40 \%$ to almost $60 \%$. This in turn would cut $\mathrm{CO}_{2}$ emissions by 2 million tons a year if the use of the waste heat from the nuclear plant avoided the need to burn an equivalent amount of natural gas and coal. The system is economically viable only if the distance between the production and use of the heat is not too great; it should be less than $100 \mathrm{~km}$.

The efficiency of electricity production can be increased by using higher temperature, this also expands the range of possible applications for process heat. Industrial processes which need process heat at high temperatures include wood pulp manufacture (around $400^{\circ} \mathrm{C}$ ); desulphurization of heavy oil in petroleum refining (around $500^{\circ} \mathrm{C}$ ); production of syngas, styrene, ethylene and hydrogen via steam reforming, Copper-Chlorine (around $550^{\circ} \mathrm{C}$ ) or Iodine-Sulphur thermochemical processes (around $800^{\circ} \mathrm{C}$ ); and the manufacture of iron, cement and glass (around $1,000^{\circ} \mathrm{C}$ ) [18]. In nuclear terms such temperatures can only be achieved by the various Generation IV reactors, which also introduce entirely new operating principles and safety features [19].

The creation of entirely new applications for nuclear power, such as process heat and hydrogen, is one of the main objectives in the development of Generation IV technologies $[18,20]$. However, not every type of Generation IV reactor will be suitable. For processes requiring temperatures in the range $500-900^{\circ} \mathrm{C}$, the gas-cooled HTR (High Temperature Reactor) and VHTR (Very High Temperature Reactor) have the clearest potential in the near future. The high-temperature Pebble Bed Reactor (PBR) is especially designed for cogeneration. HTRs could extend the use of nuclear fission beyond electricity production, replacing fossil fuels in supplying heat to petrochemical plants, steel plants and paper mills, and producing energy carriers such as hydrogen [21]. A nuclear reactor capable of producing both electricity and high-temperature heat would open up additional industrial applications. These include the possibility of producing hydrogen in industrial quantities and very efficiently, based on high temperature electrolysis or thermal decomposition of water. HTGRs are under development for use in the process industries, and may become available within a decade. They operate at peak temperature of $700-850^{\circ} \mathrm{C}$ and have thermal output in the range of $250-600 \mathrm{MWt}$. China and Japan have built test reactors. In China, the construction of an HTR-PM (High Temperature Reactor-Pebble Bed Module) reactor started in December 2012. The HTR-PM power plant has two reactors and the plant is expected to be in operation by the end of 2017 [22].

In the future, the high temperature nuclear reactor will play the important role as backbone of industrial process. Study in US, indicated the role of nuclear hydrogen cogeneration in conversion $\mathrm{CO}_{2}$ emission from cement plant to produce synthetic fuel [23]. The other similar studies also have been doing in around the world such as nuclear hydrogen cogeneration for $\mathrm{CO}_{2}$ conversion to: ammonia and urea production [15, 24], methanol [25, 26], synthetic fuels [27, 29, and 30].

At the side of demand technology, the increasing population and the narrowing of agricultural land will encourage an increase in the rate of fertilizer demand to maintain agricultural productivity $[31,32]$. As a producer of natural gas, with a high level of usage and entanglement of long-term contracts for selling Indonesian natural gas abroad, Indonesia needs to import natural gas for its petrochemical industry in the near future. The application of nuclear energy is expected to save natural gas reserves, while reducing dependence on natural gas imports. At the refinery, study indicates that to operate an oil refinery, around $10-20 \%$ of refinery products must be burned as a source of heat energy (including steaming and electricity). If nuclear energy can be used as a source of heat energy, it is expected to benefit from burning fossil fuels, which has implications for the potential for $\mathrm{CO}_{2}$ emission savings

Indonesia is currently also developing an experimental power reactor design that is expected to operate cogeneratively to generate both electricity and heat for industrial applications. The study of application high temperature nuclear energy for industry must continue to be carried out in anticipation of possible applications in Indonesia in the future.

\section{CONCLUDING REMARK}

From the analysis, it can be understood that the high temperature nuclear reactor has the ability as a massive heat source for petrochemical processes. Its utilization in the future, can be relied upon as a key technology replaces the conventional technology based on fossil fuel of natural gas. This replacement of conventional technology with high temperature nuclear reactors, capable of suppressing the rate of depletion of fossil fuel that has implications for the reduction of $\mathrm{CO}_{2}$ emission rate significantly. 


\section{REFERENCES}

[1]. Energy, Republic of Indonesia Law Number 30 of 2007.

[2]. C.O. Bolthrunis, , et.al., Using a PBMR to Heat a Steam Methane Reformer: Technology and Economics, Proceedings HTR2006: 3rd International Topical Meeting on High Temperature Reactor Technology, October 1-4, 2006 , Johannesburg, 2006.

[3]. N. Fujimoto, et.al., Present Status of HTTR Project, Achievement of 950C of Reactor Outlet Cooolant Temperature, GTHTR300C for Hydrogehn Cogeneration, OECD/NEA $3^{\text {rd }}$ Information Exchange Meeting on the Nuclear Production of Hydrogen, Oarai, 2005.

[4]. H. Masao, S. Shiozawa, Research and Development for nuclear production of hydrogen in Japan, OECD/NEA 3rd Information Exchange Meeting on the Nuclear Production of Hydrogen, Oarai, 2005.

[5]. I. Khamis, T. Koshy, K.C. Kavvadias, Opportunity for Cogeneration in Nuclear Power Plants, The 2013 World Congress on Advances in Nano, Biomechanics, Robotics, and Energy Research, Seoul, 2013.

[6]. C. Forsberg, Nuclear Power: Energy to Produce Liquid Fuels and Chemicals, American Institute of Chemical Engineer, CEP Magazine, July 2010 .

[7]. B. Lauritzen, R. K. Rajamäki, Nuclear energy efficiency improvements, DTU International Energy Report, DTU National Laboratory for Sustainable Energy, 2012.

[8]. X.Yan, et. al., A hybrid HTGR system producing electricity, hydrogen and such other products as water demanded in the Middle East, Nuclear Engineering and Design 271 (2014) 20-29

[9]. IAEA TECDOC 1085, Hydrogen as an Energy Carrier and Its Production by Nuclear Power, IAEA Publication, Vienna, 1999.

[10]. Sunardi, D. H. Salimy, E. Liun, S.M. Lumbanraja, nuclear energy as an alternative heat energy source for oil refinery. JPEN Vol. 14, No. 2, Dec. 2012.

[11]. D. H. Salimy, Sunardi, Nuclear energy as an alternative heat energy source at petrochemical industry, Prosiding Seminar Nasional Sains dan Teknologi Nuklir PTNBR - BATAN Bandung, 4 Juli 2013

[12]. ORNL-DOE, Very High Temperature Reactor (VHTR) Proliferation Resistance and Physical Protection (PR\&PP), Oak Ridge National Laboratory, 2010.

[13]. J. Ruer, Potential Use of Nuclear Energy in the Future Oil and Gas Industry, $4^{\text {th }}$ International Freiberg Conference on IGCC \& XtL Technologies, Dresden, May 2010.

[14]. D. H. Salimy, The application of high temperatur nuclear heat for urea fertilizer plant, JPEN Vol. 14, No. 1, June. 2012.

[15]. D. H. Salimy, Nuclear cogeneration application for water splitting at $\mathrm{CO}_{2}$ conversion to be urea fertilizer, JPEN Vol. 16, No. 2, Dec. 2014

[16]. M. P. Labar, et.al., Status of the GT-MHR for Electricity Production, World Nuclear Association Annual Symposium 3-5 September 2003.

[17]. B. Lauritzen, R. K. Rajamäki, Nuclear energy efficiency improvements, DTU International Energy Report, DTU National Laboratory for Sustainable Energy, 2012.

[18]. G. Locatelli, M. Mancini, N. Todeschini, Generation IV nuclear reactors: Current status and future prospects, Energy Policy 61 (2013) 1503-15202013

[19]. H.Sato, et. al., Assessment of load-following capability of VHTR cogeneration systems, Annals of Nuclear Energy 49 (2012) 33-40

[20]. J. Hampe, R. Madlener, Economics of High-Temperature Nuclear Reactors for Industrial Cogeneration, Institute for Future Energy Consumer Needs and Behavior (FCN), Working Paper No. 10, 2012.

[21]. X. Yan, et. al., A hybrid HTGR system producing electricity, hydrogen and such other products as water demanded in the Middle East, Nuclear Engineering and Design 271 (2014) 20-29

[22]. J. Ahokas, , The Role of Nuclear Power in The Future Energy System, Lappeenranta University of Technology, Master's Thesis 2015.

[23]. D. Siemer, R. Hargraves, K. Sorensen, Nuclear Ammonia: Thorium's Killer App, 8th Annual $\mathrm{NH}_{3}$ Fuel Conference, New York, 2011.

[24]. INL-DOE, Technical Evaluation Study Project No. 23843: NuclearIntegrated Ammonia Production Analysis, Idaho National Laboratory, 2010 .
[25]. D. H. Salimy, S. Alimah, , Nuclear Cogeneration Application of Hydrogen Production from Water for $\mathrm{CO} 2$ Conversion to be Methanol, JPEN Vol. 17, No. 2, Dec. 2015.

[26]. INL-DOE, Technical Evaluation Study Project No. 23843: NuclearIntegrated Methanol-to Gasoline Production Analysis, Idaho National Laboratory, 2010.

[27]. J.M. Borgard, M. Tabarant, , $\mathrm{CO}_{2}$ to fuel using nuclear power: the French case, Energy Procedia 4 (2011) 2113-2120.

[28]. C. Forsberg, Nuclear Power: Energy to Produce Liquid Fuels and Chemicals, American Institute of Chemical Engineer, CEP Magazine, July 2010 .

[29]. I. Khamis, T. Koshy, K.C, Kavvadias, Opportunity for Cogeneration in Nuclear Power Plants, The 2013 World Congress on Advances in Nano, Biomechanics, Robotics, and Energy Research, Seoul, 2013.

[30]. K. Verfondern , Overview of Nuclear Cogeneration in HighTemperature Industrial Process Heat Applications, OECD-IAEA Workshop, April 4-5, 2013, Paris

[31]. I. Hermawan, An analysis of impact of urea and TSP fertilizer subsidy policy on paddy production and achievement of food self-sufficiency in Indonesia, Jurnal Ekonomi dan Kebijakan Publik, Vol. 5, No. 1, June 2014

[32]. S. Kasiyati, et.al., Analysis of fertilizer price subsidy impact on production sector outputs and household income levels in central java, Jurnal Organisasi dan Manajemen, Vol. 6, No. 1, Maret 2010, 28-45, LPPM UT. 